\title{
Chromosome Counts of Some Doronicum (Asteraceae: Senecioneae) Taxa from Turkey
}

\author{
Seher GÜVEN ${ }^{1} * \quad$ Ünsal UMDU TOPSAKAL ${ }^{2}$ Osman BEYAZOĞLU ${ }^{3}$ \\ ${ }^{1}$ Recep Tayyip Erdogan University, Faculty of Sciences and Arts, Department of Biology, 53100, Rize, Turkey \\ ${ }^{2} Y l d d z$ Technical University, Faculty of Education, Department of Mathematics and Science Education, 34210 Istanbul, \\ Turkey \\ ${ }^{3}$ Karadeniz Technical University, Faculty of Sciences, Department of Biology, 61080 Trabzon, Turkey
}

How to cite: Güven, S., Umdu Topsakal, Ü. \& Beyazoğlu, O. (2020). Chromosome Counts of Some Doronicum (Asteraceae: Senecioneae) Taxa from Turkey. J. Anatolian Env. and Anim. Sciences, 5(4), 605-610.

Atıf yapmak için: Güven, S., Umdu Topsakal, Ü. \& Beyazoğlu, O. (2020). Türkiye'den Bazı Doronicum (Asteraceae: Senecioneae) Taksonlarının Kromozom Sayıları. Anadolu Çev. ve Hay. Dergisi, 5(4), 605-610.

\section{iD : https://orcid.org/0000-0001-8883-8489 (iD): https://orcid.org/0000-0002-0565-7891 \\ (iD): https://orcid.org/0000-0001-9744-8642}

\section{*Corresponding author's:}

Seher GÜVEN

Recep Tayyip Erdogan University, Faculty of Sciences and Arts, Department of Biology, 53100, Rize, Turkey.

凶: seher.cakmak@erdogan.edu.tr

Mobile telephone : +90 (536) 5787490

\begin{abstract}
In the present study, mitotic chromosome numbers of seven taxa of Doronicum (Asteraceae) from the northeast Anatolia, two of which are endemic to Turkey, were counted. The chromosome counts of D. haussknechtii, D. dolichotrichum, D. maximum and D. reticulatum were reported in this research for the first time. Somatic chromosome numbers were counted using squash preparations obtained from active root tips. All the investigated taxa have been proven to be diploid $(2 n=60)$. This research, consistent with the previously reported chromosome counts of the members of Doronicum, has contributed to chromosome number data of the genus.
\end{abstract}

Keywords: Chromosome count, Doronicum, Senecioneae, Anatolia.

\section{Türkiye'den Bazı Doronicum (Asteraceae: Senecioneae) Taksonlarının Kromozom Sayıları}

*Sorumlu yazar:

Seher GÜVEN

Recep Tayyip Erdoğan Üniversitesi, Fen

Edebiyat Fakültesi, Biyoloji Bölümü, 53100,

Rize, Türkiye.

凶: seher.cakmak@erdogan.edu.tr

Mobile telephone : +90 (536) 5787490
Öz: Bu çalıșmada, Kuzeydoğu Anadolu'dan iki tanesi Türkiye endemiği olan yedi Doronicum (Asteraceae) taksonunun mitotik kromozom sayıları sayılmıştır. D. haussknechtii, D. dolichotrichum, D. maximum ve $D$. reticulatum'un kromozom sayıları ilk kez bu çalışmada bildirilmiştir. Somatik kromozom sayımları, aktif kök uçlarından elde edilen ezme preparatları kullanılarak sayıldı. İncelenen tüm taksonların diploid $(2 n=60)$ olduğu kanıtlanmıştır. Doronicum üyelerinin daha önce bildirilen kromozom sayıları ile uygunluk gösteren bu araştırma, cinsin kromozom sayısı verilerine katkı sağlamıștır.

Anahtar kelimeler: Kromozom sayısı, Doronicum, Senecioneae, Anadolu.

\section{INTRODUCTION}

Doronicum L. (Asteraceae: Senecioneae) comprises 26 species and 4 subspecies naturally growing in open or forest habitats from sea level up to $5000 \mathrm{~m}$ height in a geographic region extending from Europe and North Africa to Asia (Álvarez Fernández, 2003). The members of the genus are characterized by perennial rhizomatous herbs with alternate simple leaves, one to several radiate yellow-flowered capitula comprising an involucral of herbaceous phyllaries arranged in 2 or 3 rows, and cylindrical to obovate-cylindrical shaped cypselae with 10 longitudinal ribs (Álvarez Fernández et al., 2001). The first world-wide monograph of the genus Doronicum was carried out by Cavillier (1907, 1911). In recent years, more comprehensive taxonomic revisions of Doronicum which contributed to the systematics of the genus, have been performed on the basis of morphological and 
molecular data (Álvarez Fernández \& Nieto Feliner, 1999; Álvarez Fernández et al., 2001; Álvarez Fernández, 2003). Up to now, also many karyological (Lindqvist, 1950; Skalinska, 1950; Baksay, 1956; Contandriopoulos, 1957; Favarger \& Küpfer, 1968; Lovka et al., 1972; Kuzmanov \& Ancev 1973; Löve \& Kjellqvis, 1974; Garbari et al., 1980; Van Loon, 1980; Belaeva \& Siplivinsky, 1981; Van Loon \& Oudemans, 1982; Kuzmanov \& Georgieva, 1983; Strid \& Franzén, 1983; Davlianidze, 1985; Strid \& Anderson, 1985; Chacón, 1987; Lippert \& Heubl, 1988; Tasenkevitch et al., 1989; Vir Jee \& Kachroo, 1989; Baltisberger, 1991; Ruiz de Clavijo, 1993; Pachschwöll et al., 2015) and chemical (Paolini et al., 2007; Lazarević et al., 2009; Bharti et al., 2012; Syed et al., 2014) studies including several Doronicum taxa have been reported on the genus.

The first taxonomic revision of Turkish Doronicum was performed by Edmondson (1975), who recognized 13 species and two subspecies. Since then, Álvarez Fernández (2003) has prepared the latest worldwide revision of Doronicum including several nomenclature and taxonomic clarifications, and listed 30 taxa, 10 of which also distributed in Turkey with approximately $30 \%$ endemism rate (D. cacaliifolium Boiss. \& Heldr., D. haussknechtii Cavill. and D. reticulatum Boiss.). In the present paper, we preferred to use the plant names accepted in the taxonomic treatment of Álvarez Fernández (2003) for the studied taxa. Doronicum grows in various habitats as damp meadows, streamside, shady or rocky places in Juniperus L. scrub, Abies Mill. dominated woodland, and alpine and subalpine forest margins at the altitude of 50-2900 $\mathrm{m}$ in Turkey (Edmondson, 1975). The species of subsection Macrophylla Cavill. forming the majority of Doronicum species in Turkey, was considered to be a systematically difficult taxonomic group in which indumentum characters have great importance for distinguishing the taxa (Edmondson, 1975). There have been reported some chemical (Akpinar et al., 2009), ethnobotanical (Ugurlu \& Secmen, 2007; Arı et al., 2015) and molecular (Kadıoglu, 2013) studies including only a few Turkish Doronicum taxa.

Chromosome number data are valuable today in systematics. Although the documentation of chromosome number is a priority for the conservation of the world's plant genetic resources, to date, chromosome number data of only approximately $25 \%$ of flowering plants have been determined (Stace, 2000; Garbari et al., 2012). Despite the great floristic richness of Turkey, only $15 \%$ of the vascular plant taxa have had their chromosome number investigated (Vladimirov et al., 2015). Very few counts have been reported in the literature previously for the genus Doronicum. The present study aims to report the chromosome number of seven Turkish representatives of Doronicum, two of which are endemic to Turkey. Our study will contribute to the knowledge of the chromosome number of the genus.

\section{MATERIAL AND METHOD}

Sampling: Locality information of 12 representatives of seven Turkish Doronicum taxa used for chromosome counting is given in Table 1, and the distribution of the examined taxa are shown in Figure 1 using Turkey Grid System (Davis, 1965). All specimens were first processed using the standard herbarium techniques given by Woodland (1997). They were identified using the Flora of Turkey and The east Aegean Islands (Edmondson, 1975), and stored at the Herbarium of Karadeniz Technical University, Department of Biology (KTUB).

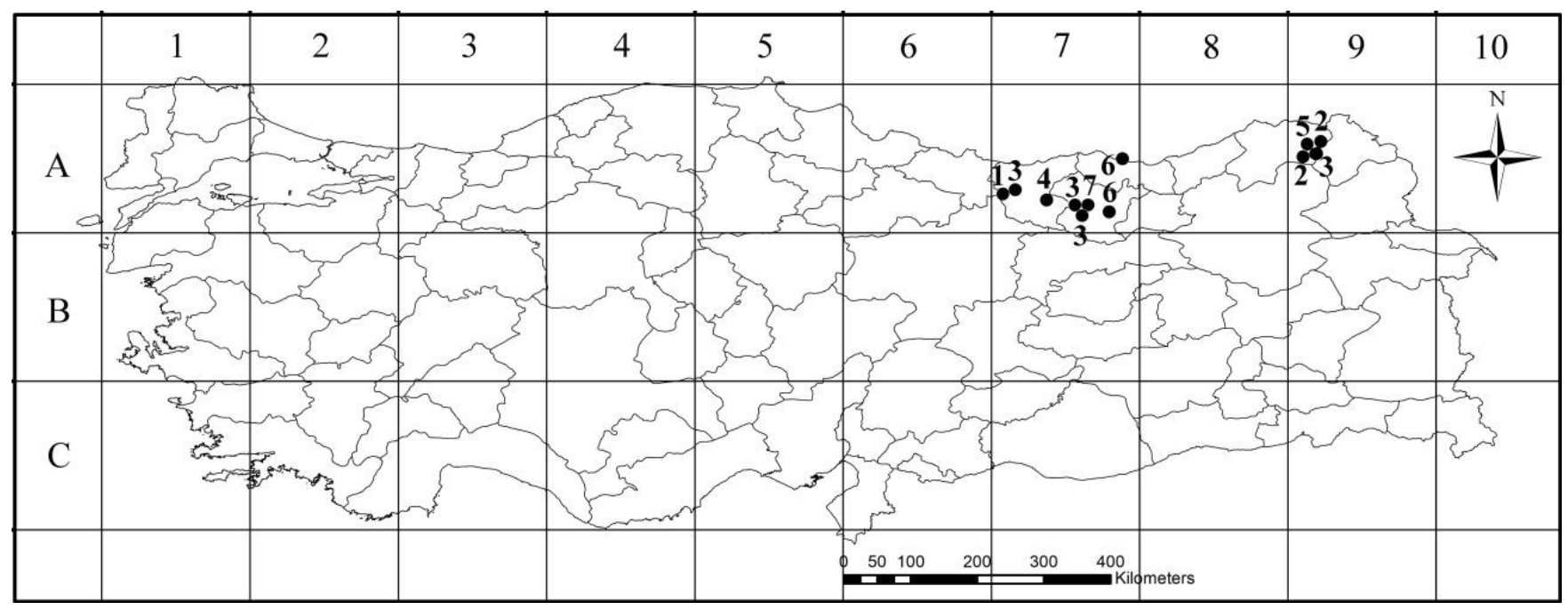

Figure 1. Distribution map of the examined taxa according to grid square system of Davis (1965) (Refer to Table 1 for explanation of accession no). 
Table 1. Locality information of the examined specimens.

\begin{tabular}{|c|c|c|c|c|}
\hline No & Taxa & Locality & Date & Voucher number \\
\hline 1 & Doronicum haussknechtii Cavill & A7Giresun: Karagöl, $2620 \mathrm{~m}$ & 02 viii 2002 & Umdu 23 \\
\hline \multirow{3}{*}{2} & \multirow{3}{*}{ Doronicum dolichotrichum Cavill. } & A9Artvin: Ardanuç, Kutul Plateau, $2200 \mathrm{~m}$ & 02 iii 2003 & Umdu 47 \\
\hline & & A9Artvin: Şavşat, Büyük Sahara, 2450 m & 04 vii 2003 & Umdu 71 \\
\hline & & A7Gümüşhane: Artabel Lakes Nature Park, 2200-2500 m & 24 vii 2003 & Umdu 91 \\
\hline \multirow{3}{*}{3} & \multirow{3}{*}{ Doronicum macrophyllum Fisch. subsp. macrophyllum } & A7Giresun: Aksu Village, $1800 \mathrm{~m}$ & 02 viii 2002 & Umdu 26 \\
\hline & & A9Ardahan: Bağdaşen Village, $2300 \mathrm{~m}$ & 06 viii 2003 & Umdu 83 \\
\hline & & A7Gümüşhane: Artabel Lakes Nature Park, 2000-2900 m & 24 viii 2004 & Umdu 97 \\
\hline 4 & Doronicum maximum Boiss. \& A.Huet & A7Giresun: Balaban Mountain, $2700 \mathrm{~m}$ & 02 viii 2002 & Umdu 24 \\
\hline 5 & Doronicum oblongifolium DC. & A9Artvin: Ardanuç, Kürdevan Mountain, 2700 m & 03 vii 2004 & Umdu 113 \\
\hline 6 & Doronicum orientale Hoffm & A7Gümüşhane: Köse Mountain, 1900m & 05 vi 2002 & Umdu 21 \\
\hline 7 & Doronicum reticulatum Boiss. & A7Gümüşhane: Artabel Lakes Nature Park, $2800 \mathrm{~m}$ & 27 vii 2002 & Umdu 31 \\
\hline
\end{tabular}

Cytological analyses: Actively growing root tips were used for somatic chromosome counts. At first, the roots of the living plants were cleaned of soil particles, and then $1-1.5 \mathrm{~cm}$ long root tips were cut off and pre-treated with $0.5 \%$ colchicine for 3 hours in the field. Then the samples were treated to the fixation process using the Carnoy solution (3:1 absolute alcohol: glacial acetic acid) for at least 24 hours at $+4^{\circ} \mathrm{C}$. Fixed root tips were transferred to $70 \%$ alcohol and stored at $+4{ }^{\circ} \mathrm{C}$ until analyses. Afterwards, the root tips were hydrolyzed with 1 $\mathrm{N} \mathrm{HCl}$ for 12 minutes at $60^{\circ} \mathrm{C}$ and stained with $2 \%$ acetoorcein for 24 hours at room temperature. Stained root tips were squashed in a drop of $45 \%$ acetic acid, and the preparations were mounted in entellan to obtain permanent slides (Jones \& Rickards, 1991; Elçi, 1994; Martin et al., 2012). The best metaphase plates, including at least ten well-spread cells, were photographed with Olympus BX51 microscope with a digital camera attachment. Also, the chromosomes were drawn from the permanent slides and counted individually by using both enlarged photographs $(10 \times 100)$ and drawings.

\section{RESULTS}

Chromosome counts of 12 accessions belonging to seven taxa of Doronicum from Turkey were presented in Figures 2-3. The somatic chromosome numbers were determined as $2 n=2 x=60$ for all the examined taxa. To the best of our knowledge, these are the first chromosome counts for D. haussknechtii, D. dolichotrichum, D. maximum and D. reticulatum.

\section{Doronicum haussknechtii Cavill. Syn:}

\section{Doronicum tobeyi J.R.Edmondson:}

This species is one of the Turkish endemics growing in streams at an altitude of $2600 \mathrm{~m}$ in B6 and A7 squares (Edmondson, 1975; Umdu, 2005). IUCN threat category of D. haussknechtii was considered as Near Threatened (NT) by Ekim et al., (2000). It proved to be $2 n=2 x=60$ (Figure 2a-b) from one Turkish population.

Doronicum dolichotrichum Cavill. Syn: D. hakkiaricum Edmondson, D. hyrcanum Widd. \& Rech. fil.:

This species is a Euxine element which was described from Caucasia. It is distributed in mountain flushes, lush alpine meadows and streamside at the altitude of 2000-2900 m in A7, A9 and C9 squares (Edmondson, 1975; Umdu, 2005). It proved to be $2 n=2 x=60$ (Figure $2 \mathrm{c}$ d) from two Turkish accessions.

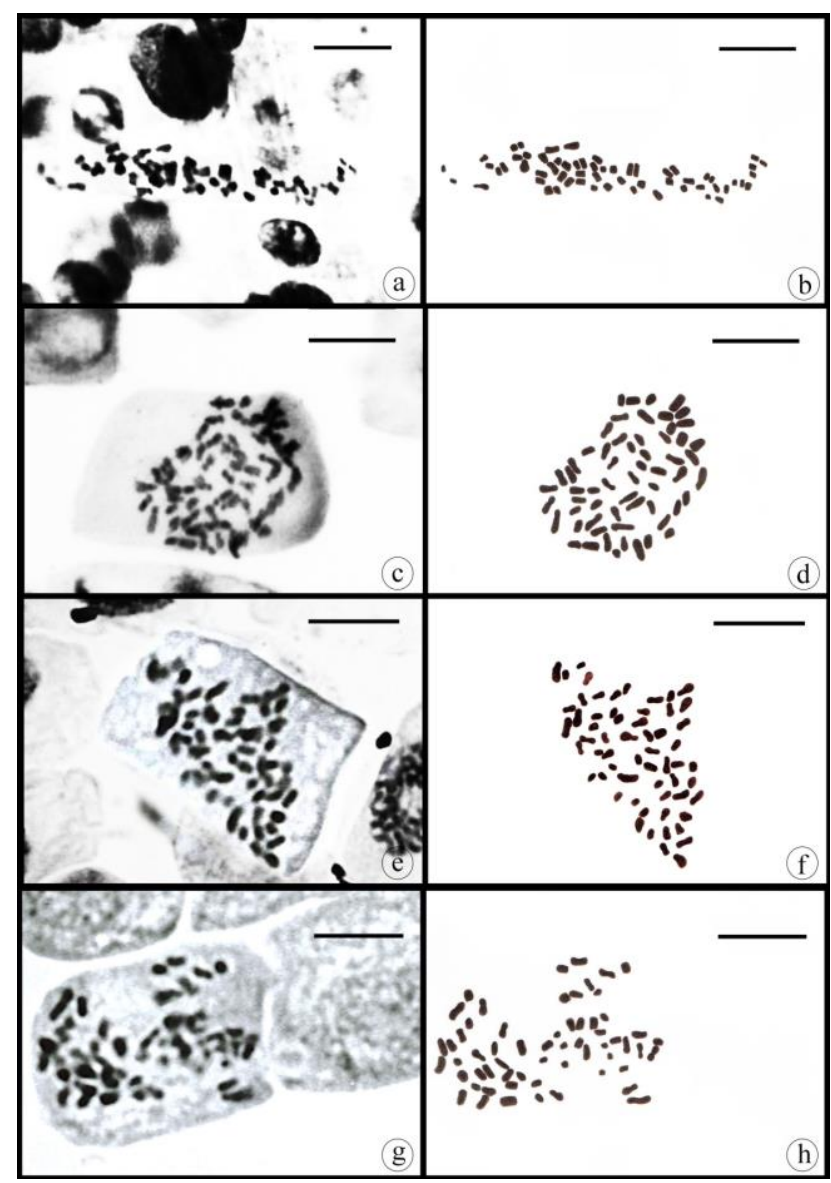

Figure 2. Somatic metaphases: a-b. D. haussknechtii (Umdu 23, $2 n=60$ ), c-d. D. dolichotrichum (Umdu 47, $2 n=60$ ), e-f. $D$. macrophyllum subsp. macrophyllum (Umdu 97, 2n=60), g-h. $D$. maximum (Umdu 24, 2n=60) (a, c, e. photo, b, d, f. drawing, bar: $10 \mu \mathrm{m})$.

Doronicum macrophyllum Fisch. subsp. macrophyllum. Syn: D. balansae Cavill., D. macrolepis Freyn \& Sint.:

This taxa, one of the Euxine elements of Doronicum described from Caucasia, is distributed at the altitude of 1480-2900 $\mathrm{m}$ in alpine and subalpine forest margins and meadows in the northeast of Anatolia (A7, A8, and A9 squares) (Edmondson, 1975; Umdu, 2005). It possessed $2 n=2 x=60$ (Figure 2e-f) in four Turkish accessions. 


\section{Doronicum maximum Boiss. \& A.Huet:}

This taxon is the most widespread species of subsect. Macrophylla Cavill in Turkey growing on the streamside and moist rocky places at the altitude of 2100$2900 \mathrm{~m}$ (Edmondson, 1975; Umdu, 2005). The somatic chromosome number was determined as $2 n=2 x=60$ (Figure $2 \mathrm{~g}-\mathrm{h}$ ) from one Turkish accession.

\section{Doronicum oblongifolium DC.:}

This species, one of the Caucasia originated Doronicum members, grows in open moist rocky places along with watercourses at the altitude of 2000-2700 $\mathrm{m}$ in the northeast of Anatolia (A9 square) (Edmondson, 1975; Umdu, 2005). The present study provided the diploid chromosome number of $2 n=2 x=60$ for $D$. oblongifolium (Figure 3a-b) from one Turkish accession.

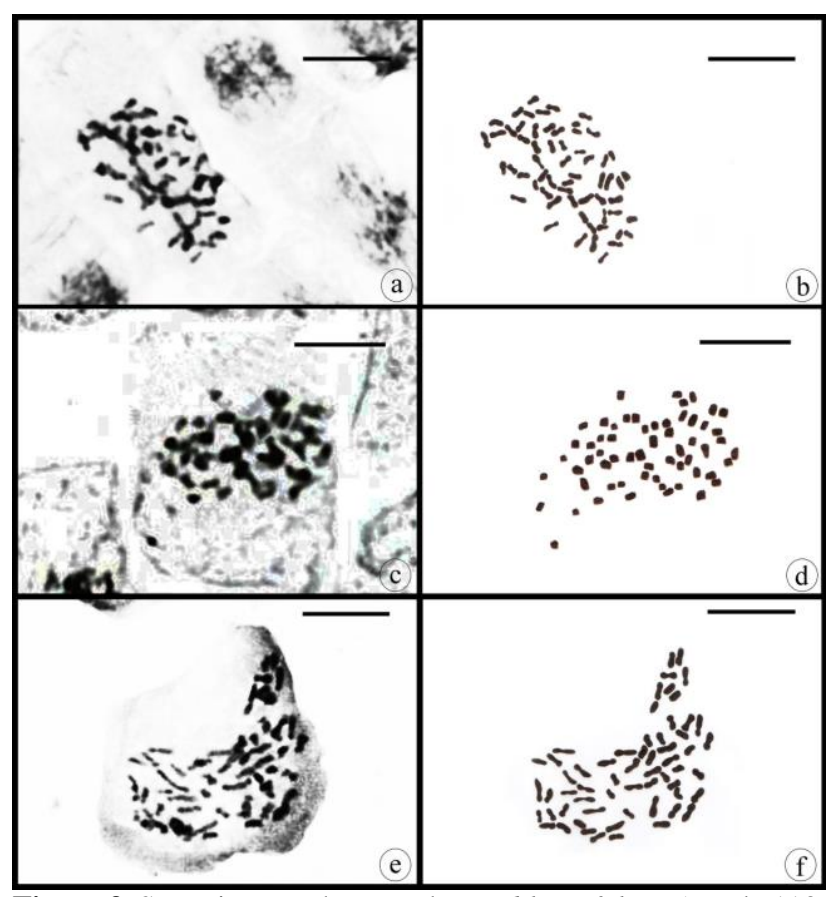

Figure 3. Somatic metaphases: a-b. D. oblongifolium (Umdu 113, $2 n=60$ ), c-d. D. orientale (Umdu $21,2 n=60$ ), e-f. D. reticulatum (Umdu 31, 2n=60) (a,c,e. photo, b,d,f. drawing, bar: $10 \mu \mathrm{m}$ ).

\section{Doronicum orientale Hoffm. :}

D. orientale is the most widespread species of the genus in Turkey which is largely restricted to the western half of the country in shady places in the forest and scrub at the altitude of 50-2000 m (Edmondson, 1975; Umdu, 2005). The somatic chromosome number of this species was determined as $2 n=2 x=60$ (Figure $3 c-d$ ) from two Turkish accessions.

Doronicum reticulatum Boiss. Syn: $D$. bithynicum Edmondson, D. bithynicum subsp. bithynicum, D. thirkei Sch. Bip. ex Boiss.

This species, endemic to Turkey, is a E. Medit. element growing on rocky slopes and Juniperus scrub at the altitude of 1450-2800 $\mathrm{m}$ in A2(A), A3, A7, B2 and B3 squares (Edmondson, 1975; Umdu, 2005). IUCN threat category of D. reticulatum was considered as Vulnerable (VU) by Ekim et al., (2000). The somatic chromosome number was counted as $2 n=2 x=60$ (Figure $3 \mathrm{e}-\mathrm{f}$ ) from one Turkish accession.

\section{DISCUSSION}

Bremer (1994) reported that the basic chromosome number of the genus Doronicum is $x=30$, which is characteristic for the "cacalioid" group in Senecioneae. However, previous authors suggested $x=10$ for the genus (Fernandes \& Queirós, 1971; Májovský \& Murín, 1987). The most recent chromosome counts related to many Doronicum taxa providing multiples of 30 ( $2 n=60)$ supported the basic number of $x=30$ for the genus and indicated that polyploidy is common within the genus (Álvarez Fernández, 2003). The chromosome number was reported as $2 n=60$ for $D$. glaciale (Wulfen) Nym. and $D$. grandiflorum Lam. (Pachschwöll et al., 2015), 2n=120 for D. plantagineum L., (Löve \& Kjellqvist, 1974; Ruíz de Clavijo, 1993) and D. stiriacum (Vill.) Dalla Torre (Murin, 1978; Pachschwöll et al., 2015) while some taxa showed both ploidy levels (e.g., D. carpetanum Boiss. \& Reuter ex Willk. \& Lange 2n=60, 120 (Chacón, 1987), D. clusii (All.) Tausch 2n=60, 120 (Tasenkevitch et al., 1989; Huber \& Baltisberger, 1992; Pachschwöll et al. 2015), D. altaicum Pall. 2n=30, 60 (Zhukova, 1967; Stepanov, 1994), D. macrophyllum 2n=30, 60 (Zhukova, 1967; Davlianidze, 1984), D. oblongifolium $2 n=40,60$ (Zhukova, 1967; Davlianidze, 1985). In the present study, the somatic chromosome number of $2 n=2 x=60$ was counted for the investigated seven taxa of Doronicum (Asteraceae) from Turkey. Our results are in agreement with the previous counts in the literature. To our knowledge, these results are new to science for $D$. dolichotrichum, a Euxine element (Figure 2c-d), D. maximum, the most widespread Doronicum in Turkey (Figure $2 \mathrm{~g}-\mathrm{h}$ ), and the two Turkish endemic taxa, D. haussknechtii (Figure 2a-b) and $D$. reticulatum (Figure $3 \mathrm{e}-\mathrm{f}$ ). Most of the species investigated in this paper are distributed at alpine regions. Polyploidisation and hybridization are considered among the major factors affecting high-mountain biodiversity for Asteraceae and also in Doronicum (Pachschwöll et al., 2015; Álvarez Fernández, 2003). Polyploid species are thought to be common in alpine environments due to their potential for increased adaptability to extreme conditions (Pachschwöll et al., 2015). However, the phenomenon stating the significant effect of polyploidization on patterns and diversification rates is still controversial (Otto \& Whitton, 2000). Besides, Mas de Xaxars et al. (2016) hypothesized that compared to polyploidy, dysploidy could be more affective in evolutionary processes in high mountain Artemisia.

D. macrophyllum subsp. macrophyllum possesses $2 n=2 x=60$ (Figure 2e-f). This is the first chromosome count for the taxon from a Turkish accession. Our result is consistent with the previous count reported by Zhukova (1967) in Russia. However, $2 n=30$ diploid chromosome number has been reported from Georgia for $D$. macrophyllum (Davlianidze, 1984). The geographical 
distribution of the taxa has been considered among the main reasons for the ploidy level variation within the plant species (Morawetz, 1984). Ozcan et al. (2008) also reported that plant taxa originating from different geographical regions can have different chromosome numbers.

The present study provided the diploid chromosome number of $2 n=2 x=60$ for $D$. oblongifolium (Figure 3a-b) from a Turkish accession for the first time. Our result is in agreement with the counts by Sietozaroia (1967) and Zhukova (1967) from Russia. However, $2 n=2 x=40$ diploid chromosome number has been reported from Georgia for D. oblongifolium (Davlianidze, 1985). This is the only count that is inconsistent with $x=30$, and according to Álvarez Fernández (2003), it should be recounted. Our counting of $2 n=2 x=60$ for $D$. orientale (Figure 3c-d) is consistent with several previous counts reported for this species by Sietozaroia (1967) in Russia, Larsen \& Laegaard (1971) in Sicilia, Strid \& Anderson (1985) in Greek, Peruzzi et al., (2012) in Italy.

The chromosome numbers of seven Doronicum taxa are reported for the first time from Turkish accessions. Although no difference was determined among the examined species in terms of somatic chromosome number, the present paper has made an important contribution to the knowledge of the chromosome number of the genus Doronicum.

\section{REFERENCES}

Akpinar, K., Yildirim, N., Üçüncü, O., Yayli, N. \& Terzioğlu, S. (2009). The volatile constituents of the flowers and leaves-stems of three Doronicum taxa from Turkey. Asian Journal of Chemistry, 21, 12251229.

Arı, S., Temel, M., Kargığlu, M. \& Konuk, M. (2015). Ethnobotanical survey of plants used in Afyonkarahisar-Turkey. Journal of Ethnobiology and Ethnomedicine, 11, 84. DOI: 10.1186/s13002015-0067-6.

Álvarez Fernández, I., Fuertes Aguilar, J., Panero, J.L. \& Nieto Feliner, G. (2001). A phylogenetic analysis of Doronicum (Asteraceae, Senecioneae) based on morphological, nuclear ribosomal (ITS), and chloroplast (trnL-F) evidence. Molecular Phylogenetics and Evolution, 20, 41-64. DOI: 10.1006/mpev.2001.0954.

Álvarez Fernández, I. (2003). Systematics of the Eurasian and North-African genus Doronicum (Asteraceae, Senecioneae). Annals of the Missouri Botanical Garden, 90, 319-389. DOI: 10.2307/3298534.

Álvarez Fernández, I. \& Nieto Feliner, G. (1999). Lectotypification of 16 species names in Doronicum (Asteraceae, Senecioneae). Taxon, 48, 801-806. DOI: $10.2307 / 1223652$.

Bharti, R., Ahuja, G., Ganapathy, S. \& Dakappa, S.S. (2012). A review on medicinal plants having Antioxidant potential. Journal of Pharmacy Research, 5(8), 4278-4287.

Baksay, L. (1956). Cytotaxonomical studies on the Flora of Hungary. Annales Historico-Naturales Musei Nationalis Hungarici, 7, 321-334.
Baltisberger, M. (1991). Cytological investigations of some Greek plants, Fl. Medit. 1, 164p.

Belaeva, V.A. \& Siplivinsky, V. (1981). IOPB chromosome number reports. Taxon, 30, 860.

Bremer, K. (1994). Asteraceae: Cladistics and Classification, Timber Press, Portland, Oregon.

Cavillier, F. (1907). Étude sur les Doronicum á fruits homomorphes. Annuaire du Conservatoire et $d u$ Jardin Botaniques de Genève, 10, 177-251.

Cavillier, F. (1911). Nouvelles études sur le genre Doronicum. Annuaire du Conservatoire et du Jardin Botaniques de Genève, 13-14, 195-368.

Chacón, A.R. (1987). Contribución al estudio taxonómico del género Doronicum L. (Compositae) en la Peninsula Ibérica. Anales del Jardín Botánico de Madrid, 43, 253-270.

Contandriopoulos, J. (1957). Contribution á l'étude caryologique des endemiques de la Corse. Annales de la Faculté des sciences de Marseille, 26, 51-65.

Davis, P.H., (1965). Flora of Turkey and the East Aegean Islands, vol. 1, Edinburgh University Press.

Davlianidze, M.T. (1985). Chromosome numbers in the representatives of the flora from Georgia. Botanicheskii Zhurnal, 70(5), 698-700.

Davlianidze, M.T. (1984). Investigatio cytogeographics speciorum nonnullarum altimontanarum e Caucaso. Notas Systematic Georgia Institute Botany Tbilissi, 40, 56-66.

Edmondson, J.R. (1975). Doronicum L. In: Davis, P.H. (Ed), Flora of Turkey and the East Aegean Islands. Vol. 5, 137-145 pp, Univ. Edinburgh Press, Edinburgh.

Ekim, T., Koyuncu, M., Vural, M., Duman, H., Aytaç, Z. \& Adıgüzel, N. (2000). Turkiye Bitkileri Kırmızı $K i t a b ı$, Van YY. Üniversitesi \& Doğa Derneği, Ankara, Barışcan Ofset.

Elçi, Ş. (1994). Sitogenetikte araştırma yöntemleri ve gözlemler, 100. Y1l Üniversitesi Yayınları, Van (Turkey).

Favarger, C. \& Küpfer, P. (1968). Contribution á la cytotaxonomie de la flore alpine des Pyrénées. Collectanea Botanica (Barcelona), 6, 325-352.

Fernandes, A. \& Queirós, M. (1971). Contribution á la connaissance cytotaxonomique des Spermatophyta du Portugal. Boletim da Sociedade Broteriana, 45, 5-21.

Garbari, F., Miceli, P. \& Monti, G. (1980). Numeri cromosomici per la Flora Italiana. Informatore Botanico Italiano, 12, 110.

Garbari, F., Bedini, G. \& Peruzzi, L. (2012). Chromosome numbers of the Italian flora. From the Caryologia foundation to present. Caryologia, 65(1), 62-71. DOI: $10.1080 / 00087114.2012 .678090$.

Huber, W. \& Baltisberger, M. (1992). IOPB chromosome data 4. International Organization of Plant Biosystematists Newsletter (Zurich), 18/19, 6-8.

Jones, R.N. \& Rickards, G.K. (1991). Practical genetics, Open University Press, Philadelphia.

Kadıoğlu, E. (2013). Doronicum orientale Hoffm. Türünün Popülasyon Düzeyinde Bazı Moleküler Özellikler Açısından Değerlendirilmesi, Karadeniz Teknik Üniversitesi Fen Bilimleri Enstitüsü. Trabzon, Türkiye, $46 p$.

Kuzmanov, B.A. \& Ancev, M.E. (1973). IOPB chromosome number reports. Taxon, 22, 461. 
Kuzmanov, B.A. \& Georgieva, S. (1983). IOPB chromosome number reports. Taxon, 32, 665.

Larsen, K. \& Laegaard, S. (1971). Chromosome studies of the sicilian flora. Botanisk Tidsskrift, 66(3), 249268.

Lazarević, J., Radulović, N., Palić, R. \& Zlatkovic, B. (2009). Chemical composition of the essential oil of Doronicum austriacum Jacq. subsp. giganteum (Griseb.) Stoj. et Stef (Compositae) From Serbia. Journal of Essential Oil Research, 21, 507-10. DOI: 10.1080/10412905.2009.9700230.

Lindqvist, K. (1950). Some results of a cytological investigation of Doronicum. Hereditas, 36, 94-102.

Lippert, W. \& Heubl, G.R. (1988). Chromosomenzahlen von Pflanzen aus Bayern und angrenzenden Gebieten. Berichte der Bayerischen Botanischen, 59, 13-22.

Lovka, M., Susnik, F., Löve, A. \& Löve, D. (1972). IOPB chromosome number reports. Taxon, 21, 337-339.

Löve, A. \& Kjellqvist, E. (1974). Cytotaxonomy of Spanish plants. IV. Dicotyledons: CaesalpiniaceaeAsteraceae. Lagascalia, 4, 153-211.

Májovský, J. \& Murín, A. (1987). Karyotaxonomicky Prehl'ad Flory slovenska, Veda Vydavatel'stvo Slovenskej Akademie Vied, Bratislava.

Martin, E., Çetin, Ö., Makbul, S., Duran, A., Öztürk, M., Boduroğlu, D. \& Eşmekaya, B. (2012). Karyology of the Scorzonera L. (Asteraceae) taxa from Turkey. Turkish Journal Of Biology, 36, 187-199.

Mas de Xaxars, G., Garnatje, T., Pellicer, J., SiljakYakovlev, S., Valles, J. \& Garcia, S. (2016). Impact of dysploidy and polyploidy on the diversification of high mountain Artemisia (Asteraceae) and allies. Alpine Botany, 126, 35-48. DOI: $10.1007 / \mathrm{s} 00035-015-0159-x$.

Morawetz, W. (1984). Karyological races and ecology of the Brazilian Duguetia furfuracea as compared with Xylopia aromatica (Annonaceae). Flora, 175, 195209.

Murin, A. (1978). In: Index of chromosome numbers of Slovakian flora. Part 6. Acta Facultatis Rerum Naturalium Universitatis Comenianae, Botanica. 26, $1-42$.

Ozcan, M., Ayaz, S.H. \& İnceer, H. (2008). Chromosome counts of some Cirsium (Asteraceae, Cardueae) taxa from Turkey. Caryologia, 61(4), 375-382. DOI: 10.1080/00087114.2008.10589649.

Pachschwöll, C., Escobar García, P., Winkler, M., Schneeweiss, G.M. \& Schönswetter, P. (2015). Polyploidisation and geographic differentiation drive diversification in a European high mountain plant group (Doronicum clusii Aggregate, Asteraceae). PLOS ONE, 10(3). DOI: 10.1371/journal.pone.0118197

Paolini, J., Muselli, A., Bernardini, A.F., Bighelli, A., Casanova, J. \& Costa, J. (2007). Thymol derivatives from essential oil of Doronicum corsicum L. Flavour and Fragrance Journal, 22, 479-487. DOI: $10.1002 / \mathrm{ffj} .1824$

Peruzzi, L., Bedini, G. \& Andreucci, A. (2012). Homploid hybrid speciation in Doronicum (Asteraceae)? Morphological, karyological and molecular evidences. Plant Biosystems, 146(4), 867-877. DOI: 10.1080/11263504.2011.634445.
Ruíz de Clavijo, E. (1993). Números cromosomáticos para la flora Española 664-690. Lagascalia, 17, 161-172.

Otto, S.P. \& Whitton, J. (2000). Polyploid Incidence And Evolution. Annual Review of Genetics, 34(1), 401437. DOI: 10.1146/annurev.genet.34.1.401

Sietozaroia, V.V. (1967). Sporogenez nekotorix vidov Doronicum L. Biull. Glav. Bot. Sad., 67, 36-42.

Skalinska, M. (1950). Studies in chromosome numbers of Polish angiosperms. Acta Societatis Botanicorum Poloniae, 20, 45-68.

Stace, C.A. (2000). Cytology and cytogenetics as a fundamental taxonomic resource for the $20^{\text {th }}$ and $21^{\text {st }}$ centuries. Taxon, 49(3), 451-477.

Stepanov, N.V. (1994). Chromosome numbers of some higher plants taxa of the flora of Krasnoyarsk region. Botanicheskii Zhurnal (Moscow \& Leningrad), 79(2), 135-139.

Strid, A. \& Anderson, I.A. (1985). Chromosome numbers of Greek mountain plants. Botanische Jahrbücher für Systematik, 107, 206.

Strid, A. \& Franzén, R. (1983). Chromosome numbers in flowering plants from Greece. Willdenowia, 13, 329332.

Syed, S.N., Rizvi, W., Kumar, A., Khan, A.A., Moin, S. \& Khan, P.A. (2014). Study to evaluate the antioxidant and hepatoprotective activities of roots extracts of Doronicum hookeri in $\mathrm{CCl}_{4}$ treated rats. European Journal of Medicinal Plants, 4(6), 675-685. DOI: 10.9734/EJMP/2014/4683.

Tasenkevitch, L.A., Vysotskaja, E.I. \& Vorobetz, N.K. (1989). Chromosome numbers in rare and endemic species of vascular plants from the Ukranian Carpathians. Botanicheskii Zhurnal, 74, 1669-1670.

Ugurlu, E. \& Secmen, O. (2007). Medicinal plants popularly used in the villages of Yunt Mountain (ManisaTurkey). Fitoterapia, 79(2), 126-131. DOI: 10.1016/j.fitote.2007.07.016.

Umdu, Ü. (2005). Doğu Karadeniz bölgesinde yayılış gösteren Doronicum L. (Compositae) türlerinin morfolojik, palinolojik ve sitolojik yönden incelenmesi. Doktora Tezi, Karadeniz Teknik Üniversitesi Fen Bilimleri Enstitüsü. Trabzon, Türkiye, $173 \mathrm{p}$.

Van Loon, J.C. (1980). IOPB chromosome number reports. Taxon, 29, 720.

Van Loon, J.C. \& Oudemans, J.J.M.H. (1982). IOPB chromosome number reports. Taxon, 31, 343-344.

Vir Jee, U.D. \& Kachroo, P. (1989). Cytogeography of some endemic taxa of Kashmir Himalaya. Proceedings of the Indian National Science Academy. Part B, Biological Sciences, 3, 177-184.

Vladimirov, V., Coşkunçelebi, K. \& Tan, K. (2015). A new diploid species of Pilosella Asteraceae) from Turkey. Turkish Journal of Botany, 39, 70-75. DOI: 10.3906/bot-1401-92

Woodland, D.W. (1997). Contemporary Plant Systematics. Andrews University Press, USA.

Zhukova, P.G. (1967). Karyology of some plants, cultivated in the Arctic-Alpine Botanical Garden. In: Avrorin NA (ed.), Plantarum in Zonam Polarem Transportatio II, pp. 139-149, Leningrad. 